\title{
Radiation-Induced Brachial Plexopathy in Breast Cancer and the Role of Surgical Treatment
}

\author{
Kenan $\mathrm{K} ı b ı c l^{1, \odot}$ Berrin Erok ${ }^{2, \odot}$ Ali Önder Atca ${ }^{3, \odot}$ \\ ${ }^{1}$ Department of Neurosurgery, Altınbas University School of \\ Medicine Bahcelievler Medical Park Hospital, İstanbul, Turkey \\ ${ }^{2}$ Cihanbeyli State Hospital, Department of Radiology, Konya, Turkey \\ ${ }^{3}$ Department of Radiology, Altınbas University School of Medicine, \\ Bahcelievler Medical Park Hospital, İstanbul, Turkey
}

\begin{abstract}
Address for correspondence Berrin Erok, MD, Department of Radiology, Cihanbeyli State Hospital, Cihanbeyli, Konya, Turkey (e-mail: drberrinerok@hotmail.com).
\end{abstract}

Indian J Neurosurg:2020;9:99-105

\begin{abstract}
Keywords

- radiation-induced brachial plexopathy

- neurolysis

- radiotherapy

- breast cancer

Objective We aimed to evaluate improvement in the pain, motor, and sensory functions after neurosurgical intervention, by objective methods in patients with radiation-induced brachial plexopathy (RIBP), as a complication of radiotherapy (RT).

Materials and Methods In our study, 11 patients, who experienced grade 3 or 4 brachial plexopathy according to the LENT-SOMA (late effects of normal tissuesubjective, objective, management, analytic) side-effect index, as a complication of RT which was performed after being operated for breast cancer, were included. In the postoperative period pain, sensation, and motor function loss were followed.

Results There was apparent regression in the pain. The mean visual analogue scale (VAS) value decreased to 4 from the preoperative VAS value of 9.4. However, no significant improvement was observed in either sensory and motor functions.

Conclusion RIBP is a progressive disease in breast cancer patients after radiotherapy. Evaluation of the results of applied surgical treatments and changes in the results with time is important to direct the treatment. Neurolysis should only be considered when other treatment methods fail and should be considered as an irreversible and potentially permanent procedure.
\end{abstract}

\section{Introduction}

Radiotherapy (RT) is an effective treatment modality which is used alone or in combination with other treatment modalities in the management of primary and metastatic malignities. However, when it is not used in appropriate doses, it can cause various complications in surrounding tissues including central and peripheral nervous systems. Radiation-induced peripheral neuropathy (RIPN) is one of the late complications of RT, which is most difficult to treat. It was first described by Stoll and Andrews in $1966 .{ }^{1}$ The dose of radiation, application technique and presence of accompanying chemotherapy are among the factors that play an important role in the development of RIPN. ${ }^{2}$ Radiation-induced brachial plexopathy (RIBP) is the best known form of RIPN.
It is a rare but a serious late complication which can appear even years after RT. Its incidence was established as approximately 1.8 to $4.9 \%$ in various clinical studies. ${ }^{3}$ It was reported that it is seen most frequently in relation with breast cancer (40-75\%) which is followed by lung cancer and lymphoma. ${ }^{4}$ The irreversible clinical course causes morbidity even in the patients whose oncological diseases were successfully managed. The management of RIBP is still controversial and there is no proven standard method. The data in the literature are mostly related with the prevention methods and conservative approaches. ${ }^{5}$ In our study, 11 patients who did not show any improvement with conservative treatment and operated for RIBP were presented. Pain, sensory, and loss of motor functions were investigated, and the results were evaluated with the clinical examination indices. 


\section{Materials and Methods}

In this retrospective study, 11 patients (- Table 1 ) who experienced RIBP, as a complication of RT which was performed after being operated for stage III or IV breast cancer (radical mastectomy, extended or super radical mastectomy), were included. Ethical Committee approval was not obtained due to the retrospective nature of the study. In the evaluation, clinical examination, radiological imaging, electromyographic test, and nerve conduction study (EMG/NCS) were used in addition to the patients' complaints. All the patients had hypoesthesia on the affected arm and all reflexes were abolic. In all the cases, active movement in the affected shoulder was 5 to 10 degrees in all directions; shoulder flexion and abduction was one-fifth, elbow flexion and extension was one to two-thirds, wrist flexion and extension was one to two-fifths, and flexion and extension of the fingers was one to two fifths. In all patients, trophic changes were present in the affected extremity. While clinical findings were evaluated by using LENT-SOMA (late effects of normal tissue-subjective, objective, management, analytic) side effect index (-Table 2) and pain were evaluated according to the visual analogue scale (VAS). Sensory functions were examined with two-point discrimination test by using Disk-Criminator

Table 1 Cases

\begin{tabular}{|c|c|c|c|c|c|c|c|c|}
\hline $\begin{array}{l}\text { Case } \\
\text { no. }\end{array}$ & Age & RT fields & CT & $\begin{array}{l}\text { Onset of } \\
\text { symptoms } \\
\text { after } \\
\text { radiotherapy } \\
\text { (mo) }\end{array}$ & $\begin{array}{l}\text { Character of } \\
\text { symptoms }\end{array}$ & İnvolve-ment & $\begin{array}{l}\text { Severity } \\
\text { of injury } \\
\text { (LENT-SOMA } \\
\text { scale) }\end{array}$ & $\begin{array}{l}\text { Localization } \\
\text { of injury }\end{array}$ \\
\hline 1 & 34 & $\begin{array}{l}\text { Supraclavicular } \\
\text { area, axilla }\end{array}$ & + & 8 & $\begin{array}{l}\text { Pain, weakness, } \\
\text { and paresthesia }\end{array}$ & $R$ & III & C5-C7 \\
\hline 2 & 42 & $\begin{array}{l}\text { Supraclavicular } \\
\text { area, axilla }\end{array}$ & + & 9 & $\begin{array}{l}\text { Pain, weakness, } \\
\text { and paresthesia }\end{array}$ & $R$ & IV & C5-T1 \\
\hline 3 & 54 & $\begin{array}{l}\text { Supraclavicular } \\
\text { area, axilla }\end{array}$ & + & 14 & $\begin{array}{l}\text { Pain, weakness, } \\
\text { and paresthesia }\end{array}$ & $\mathrm{L}$ & IV & C5-T1 \\
\hline 4 & 43 & $\begin{array}{l}\text { Supraclavicular } \\
\text { area, axilla }\end{array}$ & + & 12 & $\begin{array}{l}\text { Pain, weakness, } \\
\text { and paresthesia }\end{array}$ & $R$ & IV & C5-T1 \\
\hline 5 & 54 & $\begin{array}{l}\text { Supraclavicular } \\
\text { area }\end{array}$ & + & 15 & $\begin{array}{l}\text { Pain, weakness, } \\
\text { and paresthesia }\end{array}$ & $R$ & III & C5-C7 \\
\hline 6 & 38 & $\begin{array}{l}\text { Supraclavicular } \\
\text { area, axilla }\end{array}$ & + & 9 & $\begin{array}{l}\text { Pain, weakness, } \\
\text { and paresthesia }\end{array}$ & $R$ & IV & C5-T1 \\
\hline 7 & 29 & $\begin{array}{l}\text { Supraclavicular } \\
\text { area, axilla }\end{array}$ & + & 12 & $\begin{array}{l}\text { Pain, weakness, } \\
\text { and paresthesia }\end{array}$ & $\mathrm{L}$ & IV & C5-T1 \\
\hline 8 & 39 & $\begin{array}{l}\text { Supraclavicular } \\
\text { area, axilla }\end{array}$ & + & 13 & $\begin{array}{l}\text { Pain, weakness, } \\
\text { and paresthesia }\end{array}$ & $\mathrm{L}$ & IV & C5-T1 \\
\hline 9 & 41 & $\begin{array}{l}\text { Supraclavicular } \\
\text { area, axilla }\end{array}$ & & 15 & $\begin{array}{l}\text { Pain, weakness, } \\
\text { and paresthesia }\end{array}$ & $R$ & III & C5-C7 \\
\hline 10 & 46 & $\begin{array}{l}\text { Supraclavicular } \\
\text { area, axilla }\end{array}$ & + & 12 & $\begin{array}{l}\text { Pain, weakness, } \\
\text { and paresthesia }\end{array}$ & $R$ & IV & C5-T1 \\
\hline 11 & 48 & $\begin{array}{l}\text { Supraclavicular } \\
\text { area, axilla }\end{array}$ & & 17 & $\begin{array}{l}\text { Pain, weakness, } \\
\text { and paresthesia }\end{array}$ & $R$ & IV & C5-T1 \\
\hline
\end{tabular}

Abbreviations: CT, computed tomography; RT, radiotherapy; LENT-SOMA, late effects normal tissue task force-subjective, objective, management, analytic scale.

Table 2 LENT-SOMA scale

\begin{tabular}{|l|l|}
\hline Grade 1 & $\begin{array}{l}\text { Sild sensory deficits, no pain, no treatment } \\
\text { required. }\end{array}$ \\
\hline Grade 2 & $\begin{array}{l}\text { Moderate sensory deficit, tolerable pain, mild arm } \\
\text { weakness. }\end{array}$ \\
\hline Grade 3 & $\begin{array}{l}\text { Continuous paresthesia with incomplete paresis, pain } \\
\text { medication required. }\end{array}$ \\
\hline Grade 4 & $\begin{array}{l}\text { Complete paresis, excruciating pain, muscle atrophy, } \\
\text { regular pain medication required. }\end{array}$ \\
\hline
\end{tabular}

Abbreviation: LENT-SOMA, late effects normal tissue task force-subjective, objective, management, analytic scale.
Table 3 Biomedical Research Council (BMRC) sensory assessment

\begin{tabular}{|l|l|}
\hline Grade & Clinical examination results \\
\hline S4 & Normal sensation (2pd; 2-6 mm). \\
\hline S3+ & $\begin{array}{l}\text { Same as S3 with some recovery of two-point } \\
\text { discrimination (2pd; 7-15 mm). }\end{array}$ \\
\hline S3 & $\begin{array}{l}\text { Recovery of superficial pain and touch sensibility } \\
\text { (2pd; } 15 \mathrm{~mm} \text { ). }\end{array}$ \\
\hline S2 & Some superficial pain and touch sensation. \\
\hline S1 & Recovery of deep cutaneous pain sensibility. \\
\hline S0 & Anesthesia. \\
\hline
\end{tabular}

Abbreviation: 2pd, two-point discrimination. 
(-Table 3). Among the measurements made from the widest space toward the narrowest, the narrowest space which was sensed as being one point was recorded as the measurement length. ${ }^{6}$ After this evaluation results were recorded as normal, if the length is less than $6 \mathrm{~mm}$; as fair, if the length is 6 to $10 \mathrm{~mm}$; as poor, if the length is 11 to $15 \mathrm{~mm}$, as protective sensation only, if there is one point of perception; and anesthesia, if no point was perceived. Motor functions were examined by bilateral grasping force measurements (-Table 4). The results obtained from sensory and motor examinations were evaluated according to the Seddon scale (- Table 5). In all the patients, a preoperative (magnetic resonance) MR imaging and EMG/NCS of the brachial plexus were performed. On brachial plexus MR imaging, the nerves of the plexus next to their foraminal exits could be discriminated vaguely at the affected cervical side. Starting from the paravertebral areas, there was a widespread edema in the fatty tissues and intermuscular areas at the trajectory of proximal brachial plexus. There was diffuse edema in the perineural tissue and atrophy in the muscles at this region. Increased signal was present in the thickened nerves of the brachial plexus associated with edema. The signal intensities of the nerves of the brachial plexus near the axillary

Table 4 Biomedical Research Council (BMRC) motor force evaluation scale

\begin{tabular}{|l|l|l|}
\hline & Muscle strength (\%) & Muscle situation \\
\hline M5 & 100 & Full power \\
\hline M4 & 75 & $\begin{array}{l}\text { All synergic and independent } \\
\text { movements can be made }\end{array}$ \\
\hline M3 & 50 & $\begin{array}{l}\text { All major muscles work } \\
\text { against resistance }\end{array}$ \\
\hline M2 & 25 & $\begin{array}{l}\text { Proximal and distal muscles } \\
\text { are contracted }\end{array}$ \\
\hline M1 & 10 & $\begin{array}{l}\text { Sensible contractions of } \\
\text { proximal muscles are present }\end{array}$ \\
\hline M0 & 0 & No contraction \\
\hline
\end{tabular}

Table 5 Seddon scale

\begin{tabular}{|l|l|l|l|}
\hline & Motor & Sensory & Seddon \\
\hline Very good & 5 degrees & $\begin{array}{l}\text { The same function as in the normal side, no deformity and trophic changes, } \\
\text { stereognosis is good; no hypersensitivity; the same static 2pd with the other hand. }\end{array}$ & $\begin{array}{l}\text { Motor: } 5 \\
\text { Sensory: } 4\end{array}$ \\
\hline Good & $4-5$ degrees & $\begin{array}{l}\text { Detecting at appropriate speed, recovery of paralysis, recognizing objects with soft/ } \\
\text { hard discrimination, mild to extreme cold sensitivity, mild pulp atrophy, finger-tip } \\
\text { static separation } \leq 8 .\end{array}$ & $\begin{array}{l}\text { Motor: } 5 \\
\text { sensory: } 3\end{array}$ \\
\hline Moderate & $\geq 3$ degrees & $\begin{array}{l}\text { Sufficient capture by fingers, partial sweating, no stereognosis, pulp atrophy, marked } \\
\text { cold sensitivity, static 2pd } \geq 8 \text { mm. }\end{array}$ & $\begin{array}{l}\text { Motor: } 3 \\
\text { sensory: } 3\end{array}$ \\
\hline Poor & $\leq 3$ degrees & No sensation or severe cold sensitivity, no sweating, trophic change. & $\begin{array}{l}\text { Motor: } 0-1 \text { or } 2 \\
\text { sensory: } 0-1 \text { or } 2\end{array}$ \\
\hline
\end{tabular}

Abbreviation: 2pd, two-point discrimination.
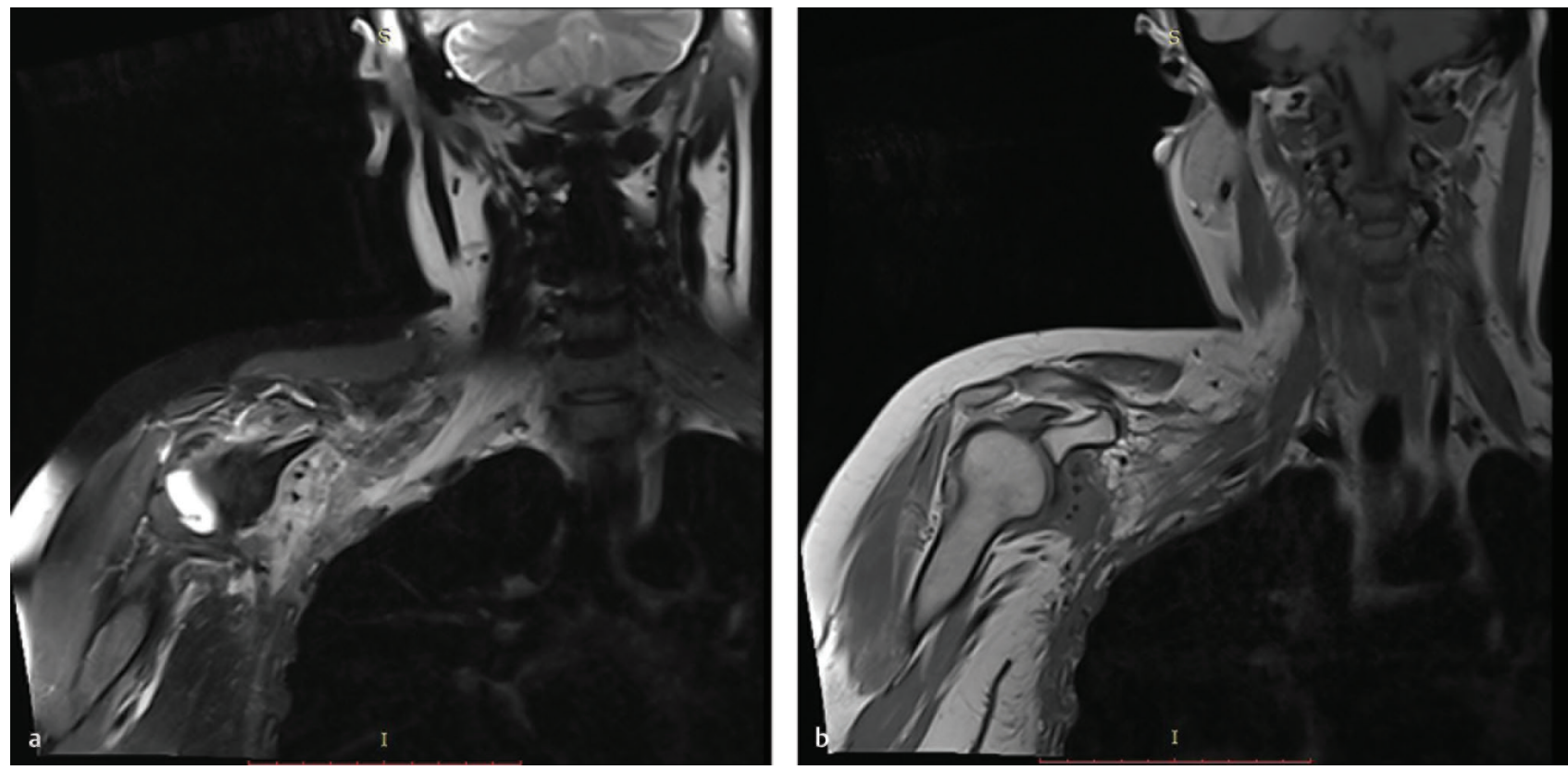

Fig. 1 MR image of one case with left RIBP. (a) The preoperative coronal STIR MR image demonstrates asymmetrical thickening and hyperintensity of left brachial plexus roots and trunks and hyperintensity in the surrounding fat and muscles, representing edema. (b) Thickened left brachial plexus roots and trunks are hypointense on preoperative coronal T1w MR image.; RIBP, radiation-induced brachial plexopathy; STIR, short inversion time inversion-recovery; T1w MR, T1-weighted magnetic resonance. 

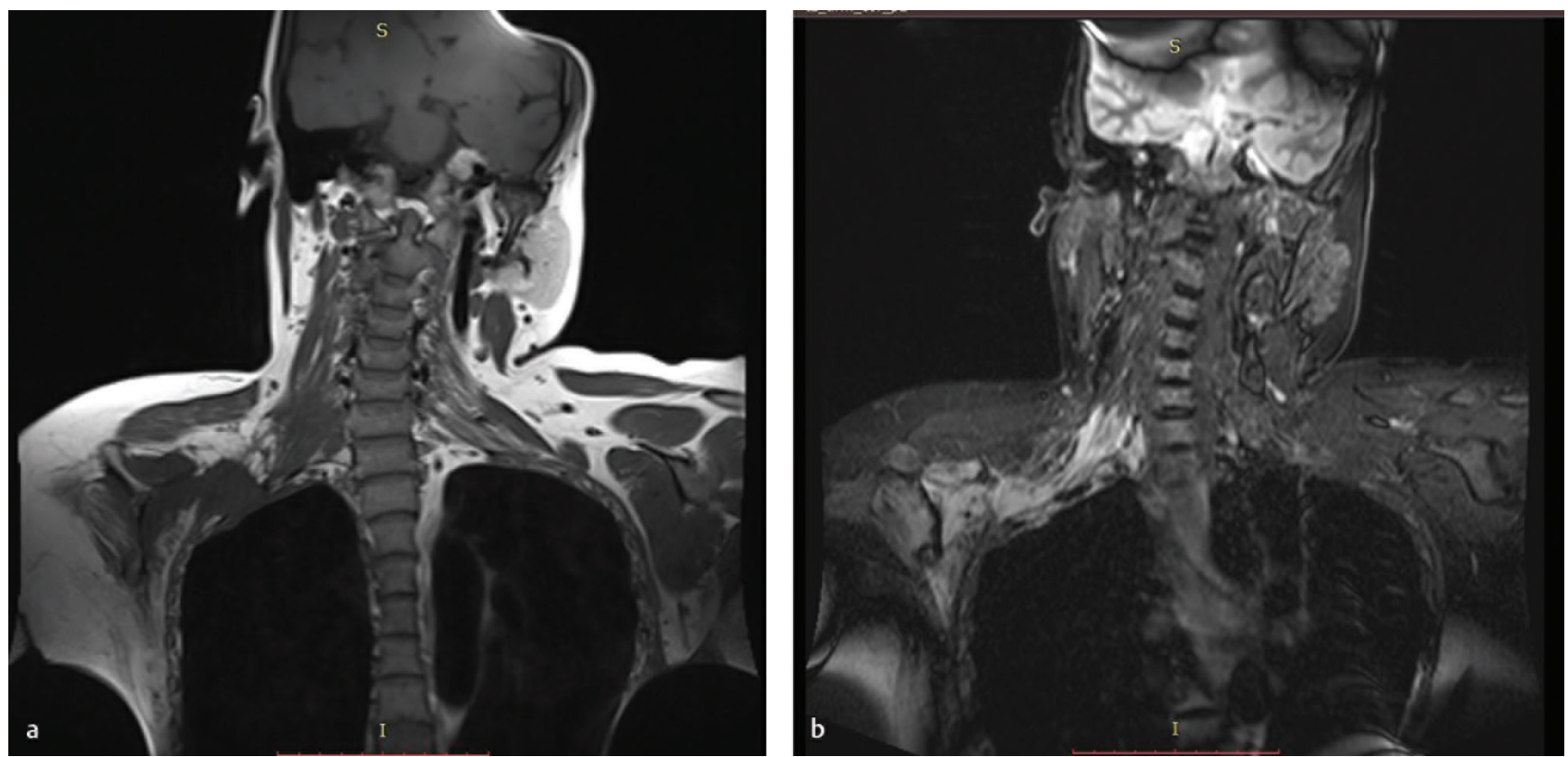

Fig. 2 MR image of one case with left RIBP. (a) The postoperative 16th month coronal STIR MR image and (b) the postoperative coronal T1w MR image demonstrates decrease in the edema in the nerves of brachial plexus and surrounding soft tissue. MR, magnetic resonance; RIBP, radiation-induced brachial plexopathy; STIR, short inversion time inversion-recovery; T1w MR, T1-weighted magnetic resonance.

region were mostly normal ( - Fig. 1 and - Fig. 2 ). Positron emission tomography-computed tomography (PET-CT) was performed in all cases for differentiation of RIBP from metastasis and there was no increase in metabolism involving the BP. The EMG/NCS revealed severe neurogenic involvement in muscles innervated by middle and lower truncus and in association with this there was a decrease in the amplitude of the transmission rate. Paraspinal EMG could not be performed due to dysesthesia and hyperalgesia. In the surgical intervention, while only infraclavicular incision was made in the five cases, in six cases both infraclavicular and supraclavicular incisions were used. Decompression and external neurolysis were applied to the affected middle and/or lower truncus nerves in all cases and abdominal subcutaneous fat is wrapped around the neurolysed BP to prevent further fibrosis and scarring.

\section{Results}

In all of our cases severe pain, weakness, and loss of sensation in the affected shoulder and arm were present. The average age was 42.54 years. Nine patients had been treated with RT in combination with chemotherapy. The mean duration of time for the appearance of the symptoms was 12.36 months. Right brachial plexus was affected in eight cases and left brachial plexus in three cases. In three patients stage III plexopathy and in eight patients stage IV plexopathy were present. All the patients used several drugs (gabapentin, pregabalin, amitriptyline, tramadol $\mathrm{HCl}$, pethidine $\mathrm{HCl}$, etc.) but had no benefit. During the surgical procedure, we observed severe atrophy in the skin and subcutaneous tissue, fibrosis in the muscular structures, loss of perineural fat tissue, and adhesion of the neural tissues to the perineural muscles. The neural tissues were yellowish due to fibrosis and the epineurium was extremely thick. The histopathological evaluation confirmed the diagnosis of scar tissues. The average follow-up was 6 months. The drugs used in the treatment of neuropathic pain were continued up to the first postoperative month and then discontinued. Contramal ampoule (Tramadol HCL) and Xanax 1-mg tablet (alprazolam) were used for pain control at early postoperative period. These drugs were discontinued on the fifth postoperative day. On postoperative tenth day, the exercise program to protect the range of motion and to strengthen the upper extremity muscles was started. The mean preoperative VAS value was 9.4. After surgery VAS value decreased to 4 with the support of medical treatment and exercises. Since no significant improvements were observed in the affected side brachial plexus in terms of motor and sensory functions (- Table 6) statistical analysis could not be performed. During this period, two of our patients died due to metastasis. In the remaining patients there was no aggravation of upper limb edema. In the follow-up of these patients, postoperative EMG/NCS was performed and no improvement in nerve conduction was established.

\section{Discussion}

Brachial plexus provides both motor and sensory innervation of the shoulder, arm, forearm, and hand. It is located in the lower cervical region between clavicula and first rib and extends to the axillary region. It is usually formed by the incorporation of ventral roots of $\mathrm{C} 5-\mathrm{C} 8$ and a large part of $\mathrm{T} 1$. $\mathrm{C} 4$ and T2 can also contribute to the brachial plexus. While brachial plexopathy (BP) can occur as a result of Hodgkin's disease, lymphoma, and lung diseases it can also develop as a result of RT performed for tumors of lung, breast, head, and neck. ${ }^{7}$ RIBP occurs most commonly following axillary irradiation due to breast cancer., ${ }^{4,8}$ The severity of side effects and 
Table 6 Results of surgical treatment of BPI after radiotherapy

\begin{tabular}{|c|c|c|c|c|c|c|}
\hline $\begin{array}{l}\text { Case } \\
\text { no. }\end{array}$ & Age & Surgical approach & $\begin{array}{l}\text { VAS } \\
\text { preop/postop }\end{array}$ & $\begin{array}{l}\text { Sensory deficit } \\
\text { preop/postop }\end{array}$ & $\begin{array}{l}\text { Motor deficit } \\
\text { preop/postop }\end{array}$ & $\begin{array}{l}\text { Seddon } \\
\text { Skalası } \\
\text { preop/postop }\end{array}$ \\
\hline 1 & 34 & İnfraclavicular & $10 / 5$ & SO/SO & M0/M1 & $1 / 1$ \\
\hline 2 & 42 & İnfraclavicular & $10 / 4$ & so/so & M0/M1 & $1 / 1$ \\
\hline 3 & 54 & Supra/infraclavicular & $10 / 6$ & so/so & $\mathrm{MO} / \mathrm{MO}$ & $1 / 1$ \\
\hline 4 & 43 & İnfraclavicular & $9 / 3$ & S0/S1 & $\mathrm{MO} / \mathrm{MO}$ & $1 / 1$ \\
\hline 5 & 54 & İnfraclavicular & $9 / 4$ & so/so & $\mathrm{MO} / \mathrm{MO}$ & $1 / 1$ \\
\hline 6 & 38 & İnfraclavicular & $9 / 5$ & so/so & $\mathrm{M} 0 / \mathrm{M} 1$ & $1 / 1$ \\
\hline 7 & 29 & Supra/infraclavicular & $10 / 6$ & So/so & $\mathrm{MO} / \mathrm{MO}$ & $1 / 1$ \\
\hline 8 & 39 & Supra/infraclavicular & $10 / 6$ & so/so & $\mathrm{MO} / \mathrm{MO}$ & $1 / 1$ \\
\hline 9 & 41 & İnfraclavicular & $9 / 3$ & So/s1 & $\mathrm{MO} / \mathrm{MO}$ & $1 / 1$ \\
\hline 10 & 46 & Supra/infraclavicular & $9 / 3$ & S0/S1 & $\mathrm{MO} / \mathrm{MO}$ & $1 / 1$ \\
\hline 11 & 48 & Supra/infraclavicular & $9 / 4$ & so/so & $\mathrm{MO} / \mathrm{MO}$ & $1 / 1$ \\
\hline
\end{tabular}

Abbreviations: BPI, brachial plexus injury; VAS, visual analogue scale.

associated damage that may develop secondary to radiation, increase in direct proportion with the dose of radiation and the duration of the exposure. Low-dose administration of RT reduces fibrosis by reducing fibroblastic activity. ${ }^{9}$ On the contrary, high doses increase the amount of fibrosis in the nerve tissue. ${ }^{10}$ Radiation application for the treatment of breast cancer was first performed in 1949. However, because of the decrease in survival due to the cardiac side effects at mortal level, hesitations occurred in the application of RT. ${ }^{6}$ In 1997, it was reported that adjuvant RT decreased local recurrence and increased survival by $9 \%$ in patients with lymph node metastasis after mastectomy or in patients whose tumors were larger than $5 \mathrm{~cm}$. Therefore, RT has again became the part of the treatment. ${ }^{2}$ Today, in all patients undergoing breast-conserving surgery, the application of RT to the breast in the postoperative period has been a standard routine practice. ${ }^{11}$ It has been shown that adjuvant RT decreases local recurrence risk in advanced stage cases and increases survival in patients with axillary metastasis. ${ }^{12} \mathrm{RT}$ is applied in two ways; chest wall irradiation and peripheral lymphatic field irradiation. In the anterior chest wall irradiation, the RT area on the medial is up to the midline of the sternum, on the lateral is up to the midaxillary line, at the top is up to the top of the head of the clavicle and at the below is up to 1 to $2 \mathrm{~cm}$ under the line of the lower end of the opposite breast area. The mastectomy scar is completely in the target volume. ${ }^{11}$ During this irradiation, especially middle and lower truncus nerves of BP in the infrascapular area can be damaged. In the peripheral lymphatic field irradiation, the supraclavicular-axillary region is irradiated from one front area. The trachea, esophagus, and medulla spinalis are protected by an angle of 12 to 15 degrees. The upper trunk of RT is irradiated in this irradiation. Middle and lower trunks are protected by the clavicle while the upper trunk is very less protected.. ${ }^{3}$ It is stated that there may be a latent period of 0 to 34 years between RT and clinical manifestations of RIBP. ${ }^{13}$ In six of our cases, RIBP developed in the first year following RT and in the remaining five cases it occurred after 2 years.
Perineural connective tissue developed in the early post-RT period causing transient electrophysiological and biochemical changes in peripheral nerves by means of vascular permeability deterioration. ${ }^{8}$ These morphological changes are hyalinization and necrosis of the medial layers of small arteries, fibrous exchange of the nerve fibers, demyelination, and thinning of epineurium and perineurium. ${ }^{3}$ In the late period, microscopic examination shows patchy axonal damage and foci of demyelination with loss of regularity of the nerve. It is accompanied by fibrosis at nerve roots and in surrounding tissues in addition to ischemia due to insufficiency of capillary networks that feed the nerves. ${ }^{8}$ Injuries in RIBP are a gradual process. Patients with LENT-SOMAscale 1 and 2 lesions may progress to grade 3 or 4 during the observation period. ${ }^{3}$ Therefore, better results can be obtained from surgical interventions performed before complete fibrosis. Vascular permeability can be achieved with perineural scar debridement and neurolysis. To date, no specific risk factor for RIBP has been found. ${ }^{8}$ RIBP prevalence was higher in young patients after RT. ${ }^{14}$ This situation can be explained by the higher dose and longer duration of the RT applied because of higher life expectancy. The mean age of our patients was 42.54 years. In two independent studies, no difference was found among patients younger and older than 55 years of age. ${ }^{3}$ Main symptoms of BP due to RT include sensory disorders, muscle atrophy and weakness, decreased reflexes, severe pain, and edema in the affected extremity parallel to the degree of fibrosis. ${ }^{3}$ Isolated motor dysfunction is extremely rare. All of our cases had severe pain, motor dysfunction, loss of sensation, and reflexes in the affected extremity. The pain was like as neuropathic pain, and was associated with dysesthesia, autonomic dysfunction, and trophic changes. The response to opioids was poor and antidepressants and anticonvulsants were being used. In cancer patients who had RT, it is important to distinguish whether the plexopathy is due to metastasis or RT. ${ }^{14}$ There is also mixed situations of BP which is due to both metastasis and RT damage. In the differential diagnosis, in addition to computed tomography, MR imaging and 
ultrasonography, PET can be used especially in the evaluation of neoplastic events. MR imaging is the best preferred imaging method to distinguish injury and tumors after RT. ${ }^{3,15}$ In addition, differential diagnosis can be made with biopsy in required cases. It was reported that MR imaging had a sensitivity of $96 \%$ and a specificity of $95 \%$ in patients with symptomatic BP following breast cancer. In MR imaging, the most common form of radiation fibrosis is the chronic form which appears hypointense in T1-weighted and T2-weighted MR images. ${ }^{16}$ MR neurography is a useful examination that provides information about the anatomy of BP, its relationship with adjacent structures and its lesions. ${ }^{7}$ We used MR imaging in all of our cases. Electrophysiological studies in the diagnosis of BP are also very valuable. EMG shows decrease in the amplitude, slowing in the transmission rate, and increased delay. ${ }^{3}$ Electrophysiological examinations performed at the appropriate time play an important role in the initial evaluation of the plexus lesions and for clinical follow-up. However, EMG does not play an important role in the differentiation of neoplastic and radiation-dependent BP. ${ }^{17}$ We performed preoperative and postoperative EMG in all of our patients. There is no proven effective treatment method to stop RIBP progression or improve neurological functions. Treatment with a combination of tocopherol and pentoxifylline has been shown to reduce radiation-induced fibrosis and possibly stabilize neurological symptoms, but larger randomized trials are lacking. ${ }^{18}$ The aim of the treatment is symptomatic relief of pain caused by nerve injury. Nonnarcotic and narcotic analgesics can be given to patients with LENT-SOMA scale grades 1 and $2 .{ }^{3}$ Also carbamazepine, amitriptyline, gabapentin, and pregabalin can be used. Since pain has a neuropathic character, medical therapy is only beneficial in reducing the pain. ${ }^{19}$ Effective treatment modalities in medical refractory cases can be listed as stellate ganglion blockage, neuroaxial opioid application, epidural dorsal column stimulation, stellate ganglion and cervical dorsal root ganglion radiofrequency application, surgical ganglionectomy, radiculotomy, and cordotomy. ${ }^{20}$ Peripheral nerve blocks and ganglion blockages have been shown to be transient in effect and are associated with increased frequency of complications with repeated applications. It is recommended that nerve blocks should be used to determine the benefit prior to neuroablative techniques. ${ }^{21}$ Physical therapy can be used to minimize functional losses and to prevent loss of joint function. However, excessive stretching exercises should be avoided because excessive tension can cause damage of fibrotic nerve or even rupture and sudden neurological decompensation may develop. Even if pain is controlled in these cases, surgical treatment should be applied to prevent the progression of the nerve damage. Grades 3 and 4 cases have no benefit from systemic steroids, anti-inflammatory drugs, and opioid analgesics. Surgical exploration is absolutely necessary in the treatment of these cases., ${ }^{3,7}$ In all of our cases, long-term conservative treatment had been used at various centers but there was no improvement in the complaints. Neurosurgical operations have been described to loosen the brachial plexus and revascularize the nerves and surrounding tissues. However, there is no fully successful treatment to reliably reverse or alter the natural course of RIBP. Omentoplasty has been proposed as an operative treatment method by Narakas..$^{22}$ Nerve transfer by microsurgery has been reported as an approach to provide reinnervation to the musculocutaneous nerves and consequently to provide restoration of elbow function. ${ }^{23}$ Surgical exploration for restoration of vascular nutrition should be performed with caution only when conservative measures fail and symptoms are severe. ${ }^{19}$ Management should be directed to optimizing symptom control and maintaining a quality of life as good as possible. Neurolysis can be performed to decompress the nerve that underwent compressive fibrosis, but the release of the nerve during this procedure may further increase the ischemia in the sheath of the nerve that is already in an ischemic bed. Microsurgical neurolysis of the brachial plexus is a controversial procedure without having conclusive results. Permanent lesions with external compression can be successfully treated with neurolysis. However, neurolysis is rarely effective in improving hand function, except when a conduction block (neuropraxis) does not recover spontaneously. When there is fibrosis on perineurium and epineurium, an incision can be made on the nerve sheath. These surgical procedures can give a good result when the fascicular pattern and endoneurial tissue are preserved. If there is fibrosis in the fascicles or a loss in the fascicular pattern, neurolysis is not successful and it is recommended to restore the continuity of the nerve with the resection of the segment and nerve graft. In most cases, it is not easy to distinguish between a recoverable nerve that can be protected and a damaged nerve that must be resected. In such cases, resection and grafting are said to be better than attempting treatment with neurolysis. ${ }^{24}$ However, greater the distance between the distal and the proximal ends of the nerve damage, lesser are the chances of recovery after grafting. Neurolysis removes the scarring tissues surrounding the intact nerve fibers. Posttraumatic scarring of the brachial plexus can stop nerve regeneration and may cause loss of function. In this environment, neurolysis may cause injury to intact fascicles. In this case, it is necessary to determine which fascicles have lost function and require grafting. Intraoperative nerve stimulation may be useful in identifying and preserving intact fascicles. Internal neurolysis may also cause fibrosis in fascicles. ${ }^{25}$ We performed internal neurolysis in all our cases in whom the continuity of epineurium was broken with a surrounding fibrotic layer. As a result of our surgical procedures, there was a significant decrease in the pain experienced by the cases but no improvement was observed in sensory and motor functions.

\section{Conclusion}

The evaluation of the results of applied surgical treatments and changes in these results with time in the patients with peripheral nerve injury is important to direct the treatment. In this respect, our study was performed to evaluate the improvement of pain, motor, and sensory functions by objective methods in patients who did not show any improvement with conservative treatment and were operated for RIBP. 
Neurolysis should only be considered when other treatment methods fail and should be considered as an irreversible and potentially permanent procedure. The most important deficiency in our study is the fact that there is a need for larger series to obtain more reliable results.

\section{Conflict of Interest}

None declared.

\section{References}

1 Stoll BA, Andrews JT. Radiation-induced peripheral neuropathy. BMJ 1966;1(5491):834-837

2 Dracham CB, Shankar A, Madan R. Radiation induced secondary malignancies: a review article. Radiat Oncol J 2018; 36(2):85-94

3 Cai Z, Li Y, Hu Z, et al. Radiation-induced brachial plexopathy in patients with nasopharyngeal carcinoma: a retrospective study. Oncotarget 2016;7(14):18887-18895

4 Dropcho EJ. Neurotoxicity of radiation therapy. Neurol Clin 2010;28(1):217-234

5 Yan M, Kong W, Kerr A, Brundage M. The radiation dose tolerance of the brachial plexus: a systematic review and meta-analysis. Clin Transl Radiat Oncol 2019;18:23-31

6 Baskar R, Lee KA, Yeo R, Yeoh KW. Cancer and radiation therapy: current advances and future directions. Int J Med Sci 2012;9(3):193-199

7 Coulier B, Van Cutsem O, Mailleux P, Richelle F. Brachial metastatic plexopathy as the inaugural manifestation of lung cancer: multimodality imaging. BJR Case Rep 2016;2(4):20150410

8 Delanian S, Lefaix JL, Pradat PF. Radiation-induced neuropathy in cancer survivors. Radiother Oncol 2012;105(3):273-282

9 StraubJM, New J, Hamilton CD, Lominska C, Shnayder Y, Thomas SM. Radiation-induced fibrosis: mechanisms and implications for therapy. J Cancer Res Clin Oncol 2015;141(11):1985-1994

10 Giuranno L, Ient J, De Ruysscher D, Vooijs MA. Radiationinduced lung injury (RILI) Front Oncol 2019;9:877

11 Skandarajah AR, Mann GB. Do all patients require radiotherapy after breast-conserving surgery.? Cancers (Basel) 2010;2(2):740-751
12 Niehoff P, Hey-Koch S. Lymph node radiotherapy instead of extended axillary surgery-the new standard. ? Breast Care (Basel) 2018;13(3):173-175

13 Al-Benna S, Schubert C, Steinau HU, Steinstraesser L. Brachial neuropathy 22 years after radiation therapy for fibrosarcoma: a case report. Cases J 2009;2:6838

14 Giglio P, Gilbert MR. Neurologic complications of cancer and its treatment. Curr Oncol Rep 2010;12(1):50-59

15 Torres C, Mailley K, Del Carpio O'Donovan R. MRI of the brachial plexus: modified imaging technique leading to a better characterization of its anatomy and pathology. Neuroradiol J 2013;26(6):699-719

16 Fan YL, Othman MI, Dubey N, Peh WC. Magnetic resonance imaging of traumatic and non-traumatic brachial plexopathies. Singapore Med J 2016;57(10):552-560

17 Mansukhani KA. Electrodiagnosis in traumatic brachial plexus injury. Ann Indian Acad Neurol 2013;16(1):19-25

18 Fan H, Kim SM, Cho YJ, Eo MY, Lee SK, Woo KM. New approach for the treatment of osteoradionecrosis with pentoxifylline and tocopherol. Biomater Res 2014;18:13

19 Fallon MT. Neuropathic pain in cancer. Br J Anaesth 2013; 111(1):105-111

20 Ding Y, Yao P, Li H, et al. CT-guided stellate ganglion pulsed radiofrequency stimulation for facial and upper limb postherpetic neuralgia. Front Neurosci 2019;13:170

21 Nabil Abbas D, Abd El Ghafar EM, Ibrahim WA, Omran AF. Fluoroscopic stellate ganglion block for postmastectomy pain: a comparison of the classic anterior approach and the oblique approach. Clin J Pain 2011;27(3):207-213

22 Narakas AO. Operative treatment for radiation-induced and metastatic brachial plexopathy in 45 cases, 15 having an omentoplasty. Bull Hosp Jt Dis Orthop Inst 1984;44(2):354-375

23 Nicoson MC, Franco MJ, Tung TH. Donor nerve sources in free functional gracilis muscle transfer for elbow flexion in adult brachial plexus injury. Microsurgery 2017;37(5):377-382

24 Michael MH, Charles EA Permanent Neural Blockade and Chemical Ablation in Pain Management Secrets. 3rd ed; 2009

25 Hems T. Nerve transfers for traumatic brachial plexus injury: advantages and problems. J Hand Microsurg 2011;3(1):6-10 